\title{
ANNUAL STREAMFLOW OF MAJOR CATCHMENT AREAS IN BULGARIA IN THE BEGINNING OF XXI CENTURY
}

\author{
N. HRISTOVA ${ }^{1}$, I. PENKOV ${ }^{1}$, K. SEYMENOV ${ }^{1}$
}

\begin{abstract}
Annual streamflow of Bulgaria in the beginning of XXI century. Estimating the annual streamflow under the climate change is a challenge for hydrology science and an important task for geography as well. There is no analysis about the basic statistical parameters of the annual runoff time-series after 2000 in scientific investigations in the country. This paper describes Bulgaria's annual streamflow during 2000 - 2016 for the main catchment areas in the country (Danube watershed, Black Sea catchment area and the Aegean Sea watershed). The work is based on publicly available data of annual streamflow. The screening of the hydrological data for homogeneity, randomness, probability distribution and the trend is based on statistical methods. The obtained results show regional differences in scale of fluctuation of hydrological variables around the norm for the referent periods, in the years with maximum and with the minimum volume of the water resources, in the probability distribution of empirical data. All timeseries are homogeneous, randomly and with the absence of the trend. The work draws a conclusion that annual streamflow of main catchment areas of Bulgaria in the beginning of XXI century is in the normal frame and with larger fluctuation than the referent periods and that the time-series statistical models need confirmation using the larger base of hydrological data. This work is the first estimation of the annual streamflow during XXI century in Bulgaria by major watersheds and it gives a new information about hydrological processes in the country.
\end{abstract}

Keywords: water resources, main catchment areas in Bulgaria, double-mass curve, homogeneity, trend analysis

\section{INTRODUCTION}

Estimation of regional annual streamflow under the rising temperature and change of precipitation patterns is an important task of hydrology and geographical science. Evaluating streamflow's fluctuations quantitatively is important for regional strategies for water resource management, for planning purposes and for the ecological conservation as well. This is also important because there are different approaches to how to measure and estimate the discharges in the last 20 years in Bulgaria (Rankova and Kroumova, 2016). National Institute of Meteorology and Hydrology (NIMH) uses numerical models to estimate the water budget components and the so-called "regionalization approach" for estimating water resources. Artinyan et al. (2017) notes that there

\footnotetext{
${ }^{1}$ Sofia University "St. Kliment Ohridski”, Faculty of Geology and Geography, Department: Climatology, Hydrology and Geomorphology. 1504 Sofia, Bulgaria E-mail: hristovaneli@abv.bg; penkov@gea.uni-sofia.bg; kalin.seimenov@abv.bg
} 
are difficulties in the application of physical hydrological models, because there is "scarce measurement data from the mountain parts of the basins combined with high diversity of relief slopes and exposures" and that "the comparison between the simulated average annual runoff by different methods and the measured one shows large differences". The regionalization approach is based on registered flow in the observed stations and on the relationship between the average annual water quantity $\left(\mathrm{Q}_{0}\right)$ and the catchment area $\left(A, \mathrm{~km}^{2}\right)$ and between the average multiannual water quantity $\left(\mathrm{Q}_{\mathrm{av}}\right)$ and the catchment area (Rankova and Kroumova, 2016, Dimitrov et al., 2017). It applies after 2006 and it is based on three reports of the Bulgarian Ministry of Environment and Water (MOEW) as "Determination of average, minimum and maximum water quantities with different repeatability", 2004, "Method of annual assessment of surface water resources in the Republic of Bulgaria with an example for 2004", 2004, Determination of average, minimum and maximum water quantities with different repeatability, 2014". The water resources till this year are calculated as the sum of rivers flow from 18 gauging stations with catchment area $70473 \mathrm{~km}^{2}(63.5 \%$ of all area of Bulgaria). The problems with measuring and estimating the water resources give the first object of this study - to analyze homogeneity of hydrological time-series as an important characteristic of the hydrologic data. The second reason is that there is no purposeful study of water resources for the last two decades in Bulgaria. The previous studies in the country have documented streamflow deviations and trend till 2000 (Chang et al., 2002, Gerasimov et al., 2004, Alexandrov and Genev, 2003, Genev and Bojilova, 2006). All these studies ascertain and note a long dry period in 1982-1994, with the maximum deviation of annual runoff in comparison to the norm (1961-1990) during 1992. Gerasimov et al. (2004), using a 105-year period and equations of the linear trend model, found out the following: decreasing of annual streamflow till 2000 for Danube watershed and for Aegean catchment area; increase (in a small scale) of the water resources for Black Sea watershed. The authors explain the result with the increase of atmospheric moisture from west-northwest to east-southeast.

Current paper's object is to describe the annual streamflow of the main catchment areas in Bulgaria after 2000 by means of deviations of the volume, homogeneity, randomness, fluctuation and the trend of the natural annual runoff.

Study area covers Danube catchment area, Black Sea catchment area and Aegean Sea catchment area in Bulgaria (Figure 1). The first two drainage basins are part of Black sea hydro-geographical region. Danube catchment area is separated as Danube River Basin Directorate, Black Sea watershed - as Black Sea Basin Directorate. Aegean Sea watershed coincide with Aegean hydrogeographical region in the country and includes two basin directorates: East Aegean River Basin Directorate and West Aegean River Basin Directorate. Danube catchment area in Bulgaria gives $30,5-42,4 \%$ of the annual volume of water resources in the country, Black sea's catchment area - between 1,7\% and 7,9\%, while the catchment area of Aegean Sea in Bulgaria - from 50,6\% to 66,3\% of the annual water resources. 


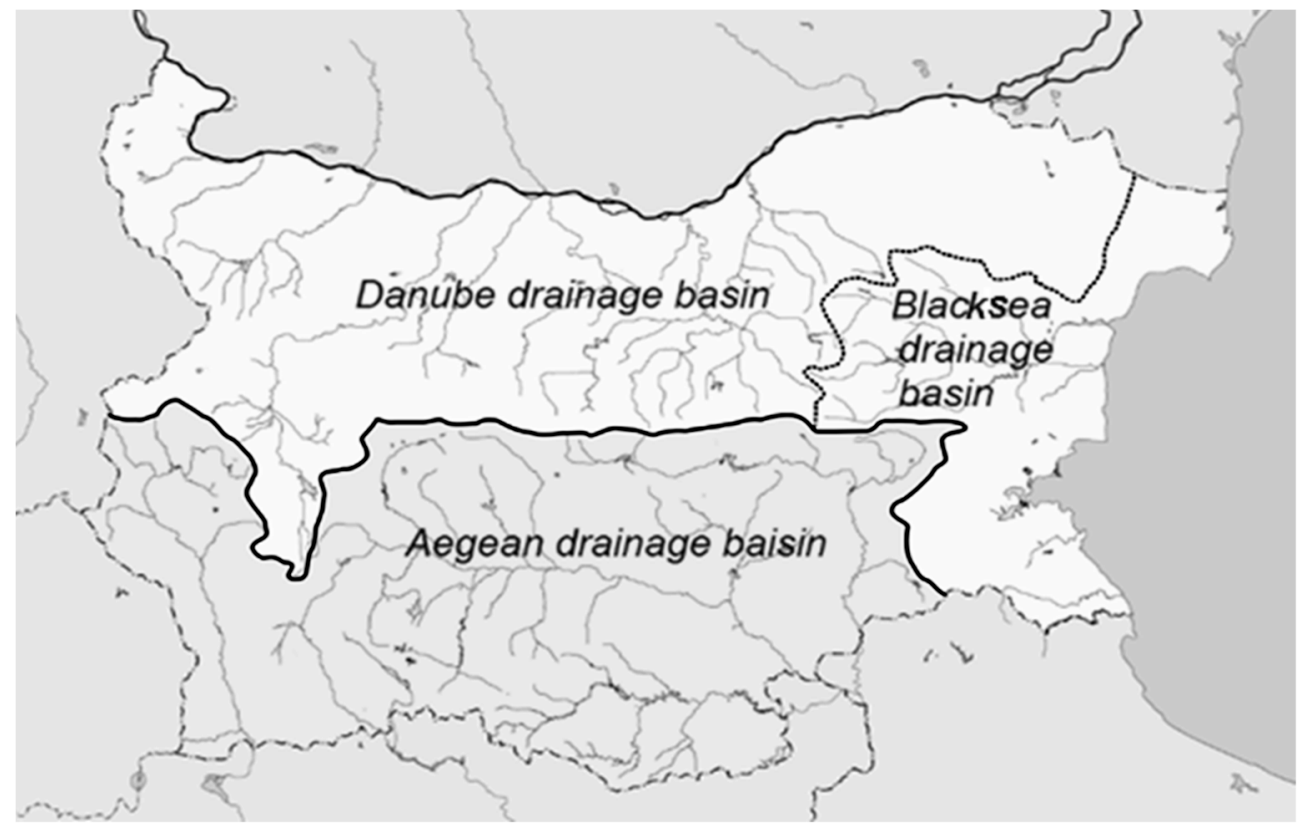

Fig. 1. Major catchment areas in Bulgaria

\section{MATERIAL AND METHODS}

Annual streamflow records for every drainage basin were obtained from the NIMH's “Annual bulletin". The annual runoff is the evaluated streamflow towards previous year and collate $(\%)$ with the mean streamflow for three 30 -years referent periods: $1961 \div 1990,1971 \div 2000$ and $1981 \div 2010$. NIMH recommends the $1971 \div 2000$ period as the most representative. "Annual bulletin" (2010) gives information for a longer period of observation, namely $1961 \div 2006$. The publicly available data for 2000 - 2016 gives 17-year time-series records for annual runoff. NIMH publishes information about Bulgaria's annual rivers flow (after 2000) for the River Basin Directorates, too. Danube River Basin Directorate coincide with Danube catchment area and Black Sea Basin Directorate - with catchment area of Black sea. East Aegean River Basin Directorate and West Aegean River Basin Directorate cover the catchment area of Aegean Sea and therefore the hydrological data for Aegean Sea catchment area is calculated as a sum of the runoff of these two Directorates. The changes in the annual streamflow were analyzed for the calendar year.

Screening of hydrologic data for homogeneity is based on graphical as well as statistical approaches: simple technique "double-mass curve" and nonparametric Pettitt's test which is useful for evaluating the occurrence of abrupt changes in hydrological records also (Searcy and Hardison, 1960, Machiwal and Jha, 2012). Pettitt's test identifies the break in the middle of the series and does not need assumption for normality distribution. The hydrological series are tested for their convergence with the normal distribution with several nonparametric tests but 
results are analyzed by Shapiro-Wilk test because, according to Thode (2002), it is the best choice for testing the normality of data and it provides better power than the Kolmogorov-Smirnov test (Steinskog et al., 2007). The "unit root tests" and Kwiatkowski-Phillips-Schmidt-Shin (KPSS) test for stationarity was applied. The non-parametric Mann-Kendall test was used to evaluate the trends.

\section{RESULTS}

The study shows different deviations by sign and scale around the norm for the referent periods in every catchment area. The volume of annual streamflow in Danube catchment area closely toward $\bar{Q}_{1961-1990}$ and less than $\bar{Q}_{1971-2000}(-11,6 \%)$. Similar departures are found for the Aegean Sea catchment area - positive deviation of the volume of water resources for the first period $(2,5 \%)$ and decrease towards the second referent period. Annual runoff for Black Sea catchment area is less than $\bar{Q}_{1961-1990}(-12,0 \%)$ and it is a little above $(4,8 \%)$ in comparison to $\bar{Q}_{1971-}$ 2000. The following results explain this: the second referent period, 1971-2000, includes the long dry period in Bulgaria as 1982-1994; the precipitation in Black Sea catchment area is above the norm during 1995-2011. The maximum deviations are during the wet and the dry years and are at their maximum for Danube Sea catchment area (Table 1). The values of coefficient of variation are little larger than $C_{v}$ for 1961-1990 because the time-series is without a very large amount of data and include extreme observations (Table 1).

Table 1. Volume of annual streamflow series and maximum deviations toward the norm of referent periods in the catchments areas

\begin{tabular}{|c|c|c|c|c|c|c|c|c|c|c|}
\hline \multirow{3}{*}{$\begin{array}{l}\text { Catchmen } \\
\text { t area }\end{array}$} & \multirow{3}{*}{$\begin{array}{c}\bar{Q}_{2000-2016} \\
\left(\times 10^{6}\right) \\
\mathrm{m}^{3}\end{array}$} & \multicolumn{8}{|c|}{ Maximum deviation (\%) of $\bar{Q}_{2000-2016}$} & \multirow{3}{*}{$C_{v}$} \\
\hline & & \multicolumn{4}{|c|}{$\bar{Q}_{1961-1990}$} & \multicolumn{4}{|c|}{$\bar{Q}_{1971-2000}$} & \\
\hline & & $\%$ & Year & $\%$ & Year & $\%$ & Year & $\%$ & Year & \\
\hline $\begin{array}{l}\text { Danube } \\
\text { catchment } \\
\text { area }\end{array}$ & 6265.7 & 119.2 & 2005 & -60.6 & 2001 & 145.3 & 2005 & -55.9 & 2001 & 0.46 \\
\hline $\begin{array}{l}\text { Black Sea } \\
\text { catchment } \\
\text { area }\end{array}$ & 1581.1 & 74.6 & 2005 & -88.2 & 2002 & 89.3 & 2005 & -87.2 & 2002 & 0.58 \\
\hline $\begin{array}{l}\text { AegeanSea } \\
\text { catchment } \\
\text { area }\end{array}$ & 9333.2 & 101.7 & 2015 & -38.9 & 2011 & 136.1 & 2015 & -28.6 & 2011 & 0.39 \\
\hline
\end{tabular}

The work finds geographical differences in the very wet and very dry years in the catchment areas of the investigated period (Table 1). The annual streamflow of Danube watershed is largest during 2005 and above (with 28\%) annual runoff for the wettest 1956 year for this region till 2000 or for all observation period. This means that the annual runoff in north Bulgaria in 2005 is the absolute maximum 
streamflow. The very wet year in Black Sea catchment area is 2005, but the volume of the annual runoff is less (-15\%) compared to 1956 - wettest year for east part of the country till 2000. Results show another picture for Aegean Sea catchment area. The wettest year in this hydro-geographical region is 2015 . The volume of water resources is less $(-16 \%)$ in comparison to 1963 or toward the wettest year till 2000 . There are differences in the years of very dry events in the watersheds. The very dry year in the investigated period for Danube catchment area is 2001 as it is for the entire country. Driest year for the Black Sea catchment area is 2002 and 2011 for the Aegean Sea watershed. In comparison to 1990 - the driest year till 2000, the volume of runoff shows the following: water resources during 2001 for Danube catchment area and during 2011 for Aegean Sea watershed are higher (with 42\% and $45 \%$ respectively) compared to 1990 ; Black Sea watershed's annual runoff for 2002 is less in comparison to 1990 (-45\%). Therefore, 2002 year is the driest year for Black Sea watershed for all of the observation periods in the country.

The given sequences of observations are relatively homogeneous - there is no change of the double mass curves (Figure 2). The result of homogeneity according to Pettitt's test is another - computed $p$-value is less than the significance level $\alpha=0,05$ for Danube watershed $(p=0,021)$ and for Black sea catchment $(p=0,038)$.
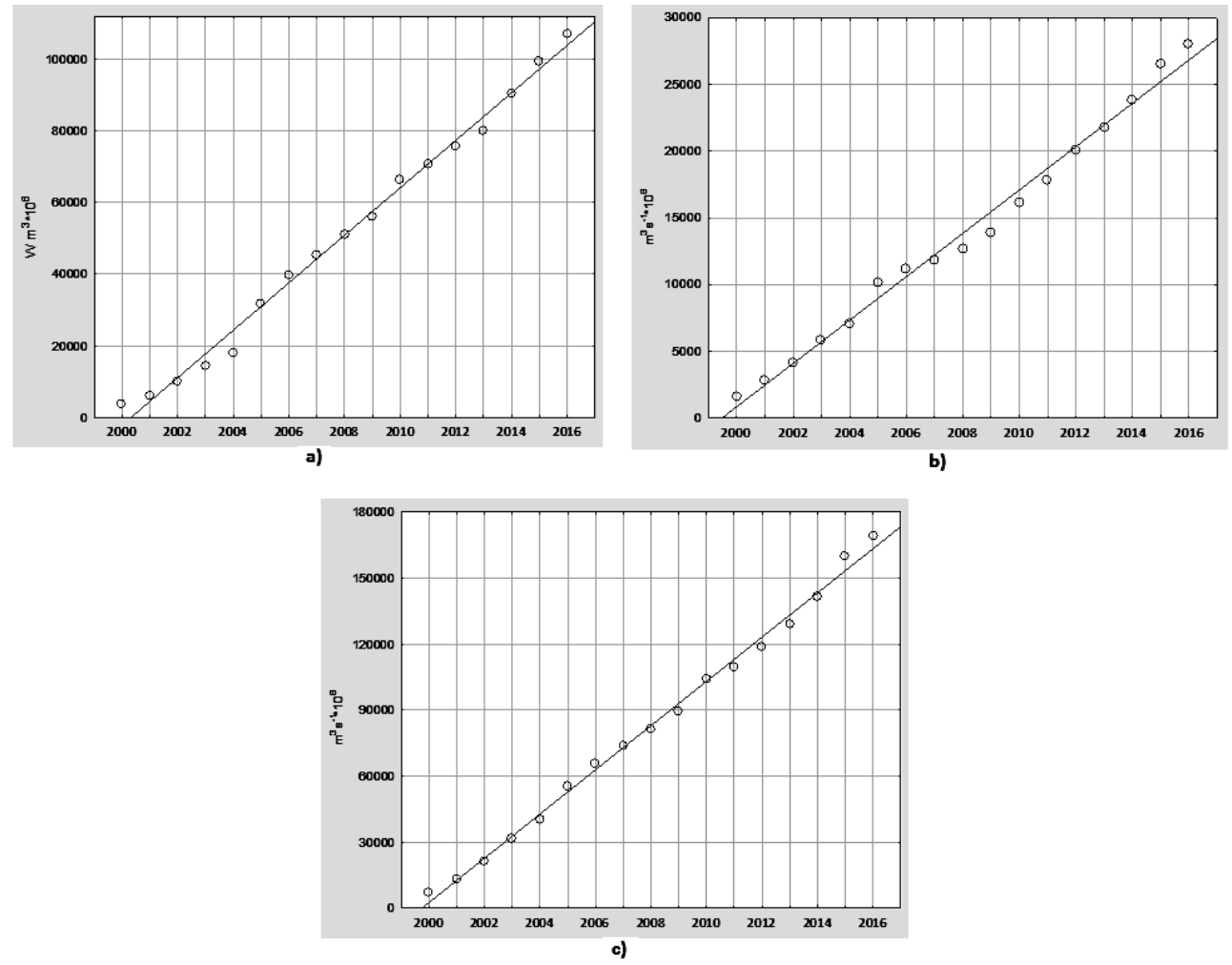

Fig. 2. Double-mass curve of annual streamflow for 2000-2016:

a) Danube catchment area; b) Black sea catchment area; c) Aegean Sea catchment area 
These results are confirmed by Wilcoxon signed-rank test (two-tailed). The time series record of annual streamflow of Aegean Sea watershed is homogeneous according to Pettitt's test ( $p$-value is 0.574 or greater than the significance level) and Wilcoxon signed-rank test. The result means that all of the data in every time series refer to the same phenomena in observation under identical condition (Mauro, 2017) and the hydrological data were recorded with similar instruments and techniques.

Series of hydrological variables display asymmetric distribution patterns with positive skewness. The right skewness is typical for most hydrologic variables due to the influence of natural phenomena (Viessman and Lewis, 2003).

The all three time-series are randomly distributed according to the onesample runs test - tool for assessing whether a sequence of observations variable can be considered random. The Kwiatkowski-Phillips-Schmidt-Shin test confirms stationarity for annual streamflow time-series of every catchment area. The "unit root tests" (Dickey-Fuller test and Phillips-Perron test) give other result: hydrological time-series of Danube watershed and of Aegean Sea catchment area are not stationarity in contrast to the time-series of Black Sea catchment area. This contradictory result is probably being due to the series' length and it needs additional studying on longer and wider base of data series.

The outcome of standard testing techniques for normality of hydrological data shows regional differences of the probability distribution. According to nonparametric tests - Shapiro-Wilk, Anderson-Darling and Lilliefors and Jargue-Bera, the assumption of normality is rejected for annual runoff time-series of Danube catchment area and of Aegean watershed (Table 2). The data distribution in the series is not improved after Box-Cox transformation.

Table 2. Tests for normality distribution of sequences of observations in the major catchments areas

\begin{tabular}{l|c|c|c|c}
\hline \multirow{2}{*}{ Catchment area } & \multicolumn{4}{|c}{ Test } \\
\cline { 2 - 5 } & $\begin{array}{c}\text { Shapiro- } \\
\text { Wilk }\end{array}$ & $\begin{array}{c}\text { Anderson- } \\
\text { Darling }\end{array}$ & Lilliefors & Jarque-Bera \\
\hline Danube catchment & 0,053 & 0,037 & 0,040 & 0,289 \\
Black Sea catchment & 0,711 & 0,858 & 0,935 & 0,733 \\
Aegean Sea catchment & 0,056 & 0,046 & 0,018 & 0,213 \\
\hline
\end{tabular}

Log-normal distribution is accepted for time-series of Danube watershed and for time-series of Aegean Sea hydro-geographical region as more closely to the empirical distribution (Fig. 3 and 4). Chi-square tool confirms this distribution: $p=$ 0,432 for Danube catchment area and the risk to reject Log-normal distribution while it is true is $43,21 \%$; $p=0,087$ for Aegean catchment area and we cannot reject this distribution. The same techniques show normality distribution of time records for Black Sea catchment area (Table 2, Fig. 5). The parameter of log-normal distribution is $\mu=8.65$ (standard error is 0.13 ) with likelihood function -175.05 . 


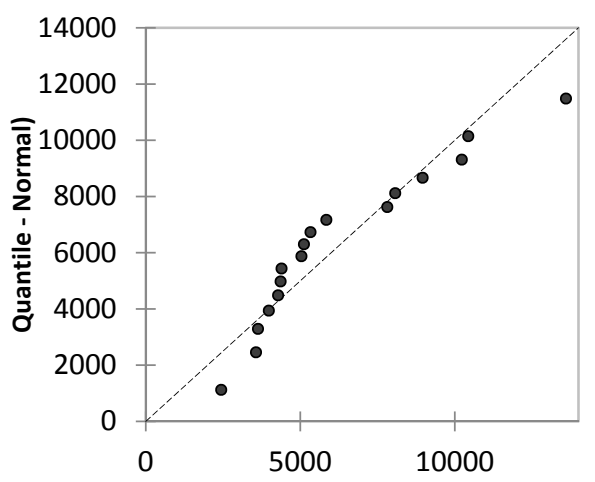

a)

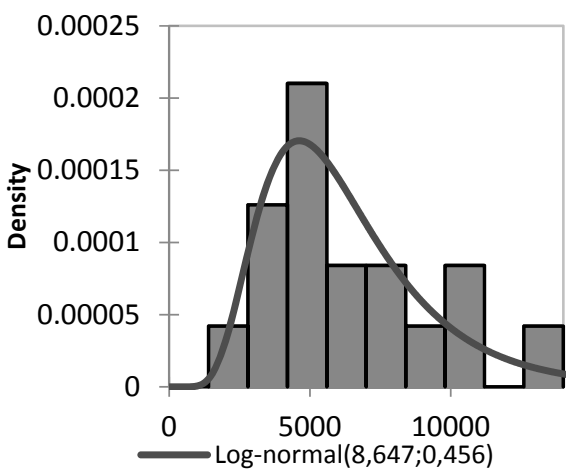

b)

Fig. 3. Q-Q plot (a) and empirical distribution(b) of the annual runoff record of Danube catchment area

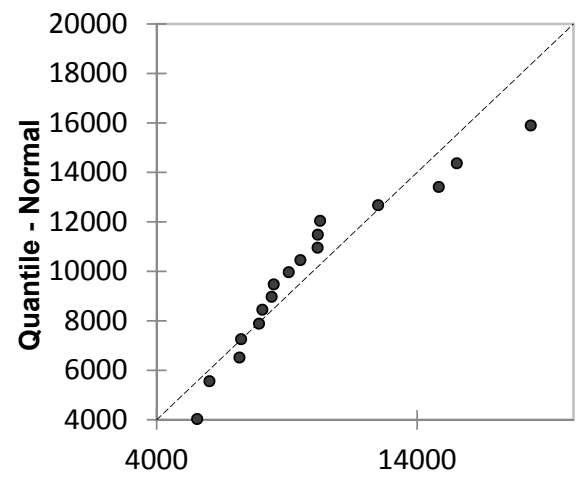

a)

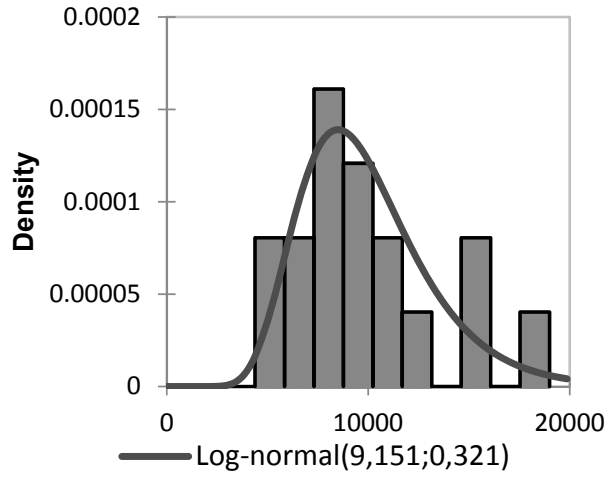

b)

Fig. 4. Q-Q plot (a) and empirical distribution(b) of the annual runoff record of Aegean Sea catchment area

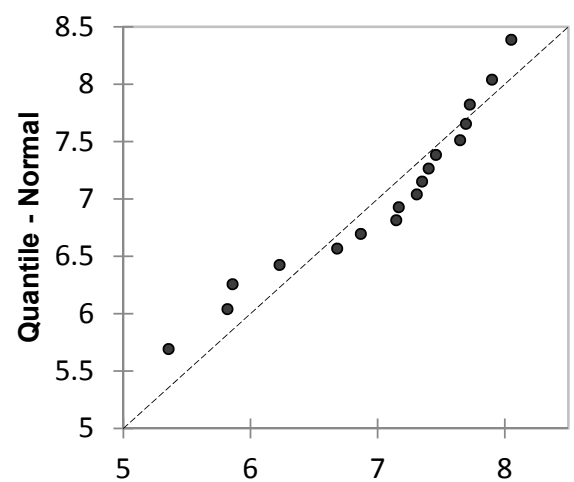

a)

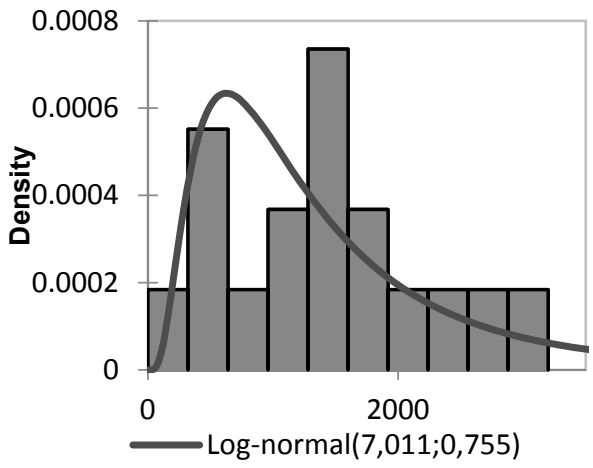

b)

Fig. 5. Q-Q plot (a) and empirical distribution (b) of the annual runoff record of Black Sea catchment area 
There is no obtained result for the model of the distribution of time-series for catchment areas in the previous studies in the country and the current study, not have the base for comparison. The found out time-series models need confirmation using a larger base of hydrological data. The Mann-Kendall test indicated no trend in series of hydrological variables (Table 3 ). There is no date at which there is a change in the data according to Pettitt's test or no statistically significant shifts occurred in the data. The visualization of the data show alternation of dry, normal and wet years in the investigated period (fig. 6 and fig.7). Further explanation could be found in the short records and the absence of trend in precipitation (Rachev and Dimitrova, 2016).

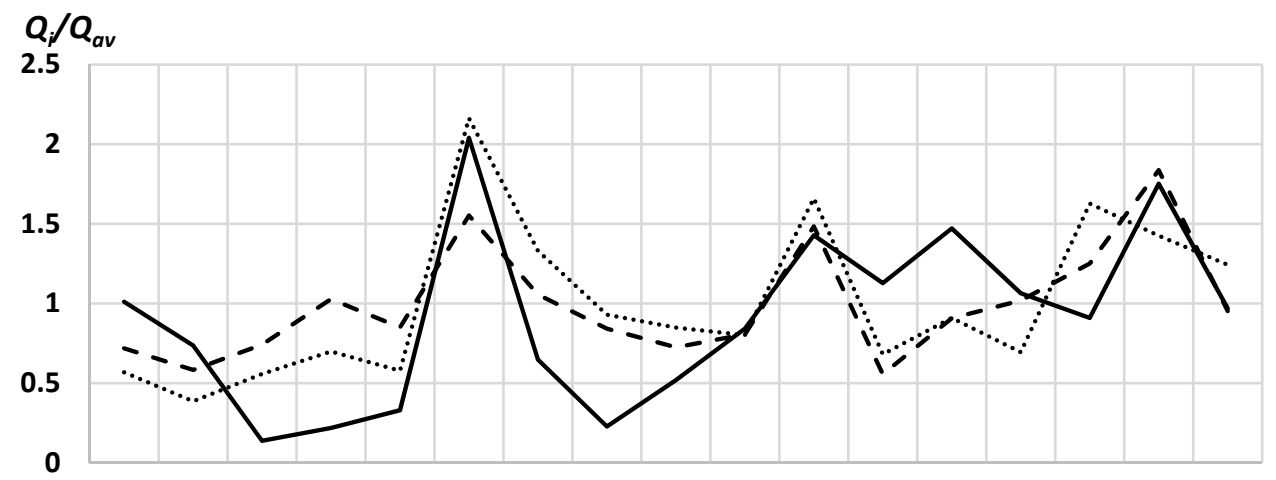

20002001200220032004200520062007200820092010201120122013201420152016

.......... Danube watershed — Black Sea watershed - - - Aegean Sea watershed

Fig. 6. Variability of the annual runoff

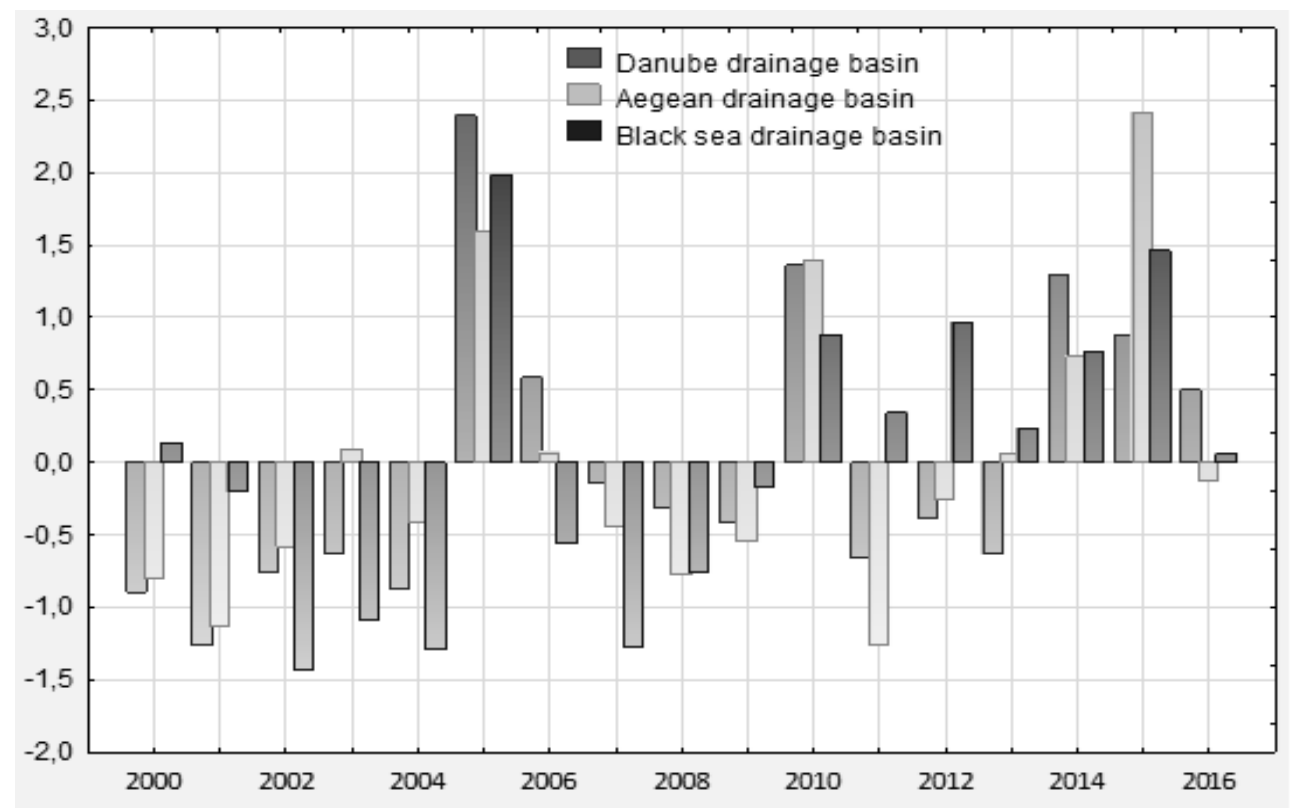

Fig. 7. Standardized meanings of the annual runoff 


\section{CONCLUSION}

The results of this work show the following: a) annual streamflow in main watersheds in the country are not significantly impacted by rising temperature - the volume of the annual runoff in 2000-2016 fluctuates around the norm for the referent periods; $b$ ) two values of annual streamflow in the investigated period are absolute for the all observation period in the catchment area - the annual streamflow in Danube watershed in 2005 as absolute maximum and the volume of annual runoff in the Black Sea watershed in 2002 as the absolute minimum; c) hydrological time-series are homogeneity and randomly; d) empirical series of hydrological variables of Black Sea catchment area is approximated by the Normal distribution in contrast of other watersheds where time-series show Log-normal distribution; e) there is no trend in the annual runoff for all catchments area.

This work is a first step in studying the annual streamflow of the main catchment areas in Bulgaria. Results give important information about the pattern of hydrological time series in these regions and it is a base for follow-up investigating. This work complements previous studies and holds potential for hydrological forecasting.

\section{REFERENCES}

1. Alexandrov V., Genev M. (2003), Climate Variability and Change Impact on Water Resources in Bulgaria. European Water, 1/2: 25-30. Available from: http://www.ewra.net/ew/pdf/EW_2003_1-2_04.pdf, accessed on December, 12, 2017.

2. Annual bulletin. NIMH. http://hydro.bg/bg/data/reki.

3. Artinyan, E., Dimitrov D., Kroumova K., Rankova, M. (2017), Annual water resources assessment using different observations and models. Danube conference 2017. 215-222. Available from: http://www.danubeconference2017.org/images/ebook_full_texts_dc_2017.pdf, accessed on December, 10, 2017

4. Chang, H., Knight C. G., Staneva M., Kostov D. (2002), Water resource impacts of climate change in southwestern Bulgaria. GeoGournal, 57, 3, 159-168.

5. Dimitrov, D., Rankova, M., Kroumova, K. (2017), Water resources statistical estimates in Bulgaria characteristics and future. Danube conference 2017. 470-475. Available from: http://www.danubeconference2017.org/images/ebook_full_texts_dc_2017.pdf, accessed on December, 10, 2017

6. Genev M., Bojilova E. (2006), Variations of the river runoff in Bulgaria during XX century. Available

from: https://www.researchgate.net/publication/287199125_VARIATIONS_OF_THE_RIV ER_RUNOFF_IN_BULGARIA_DURING_XX_CENTURY, accessed ${ }^{-}$on September, 21, 2017.

7. Gerasimov, Str., Genev M., Bojilova E., Orehova T. (2004). Water resources of Bulgaria in the drought period 1982-1994 (probable scenarios for future development). Heron Press, Sofia, 1-104. Available from: https://www.researchgate.net/publication/287596035_Vodnite_resursi_na_Blgaria_pr ez_perioda_na_zasusavaneto_1982-1994_Veroatni_scenarii_za_bdeso_razvitie, accessed on October, 16, $201 \overline{7}$. 
8. Machiwal, D., Jha, M.K. (2012), Hydrological Time Series Analysis: Theory and Practice. Springer Science.

9. Mauro N. (2017), Fundamentals of Statistical Hydrology, $1^{\text {st }}$ ed., Springer.

10. Rachev, N. Dimitrova D. (2016), Changes in average temperatures and precipitation in Bulgaria for the period 1995-2012. Annual of Sofia University "St. Kliment Ohridski", Faculty of Physics, 109, 1-25. [In Bulgarian]. Available from: http://www.phys.uni-sofia.bg/annual/archive/109/full/GSU-Fizika-109_07.pdf, accessed on November, 20, 2017.

11. Rankova, M., Kroumova, K. (2016), Possibility for water resources assessments of surface water in Bulgaria, Vodno delo, 1/2, 22-26. [in Bulgarian]

12. Searcy, T. K., Hardison, C.H. (1960), Double-Mass Curves. Manual of Hydrology: Part 1. General Surface-Water Techniques. U.S. Geological Survey Water-supply Paper 1541-B. USGS, Washington, 66 p. Available from: https://pubs.usgs.gov/wsp/1541b/report.pdf, accessed on September, 21, 2017.

13. Steinskog DJ., Tjøstheim Dag B., Kvamstø Nils G. (2007), A Cautionary Note on the Use of the Kolmogorov-Smirnov Test for Normality. American Meteor Society, 135, 1151-1157. Available from: http://journals.ametsoc.org/doi/full/ 10.1175/MWR3326.1, accessed on December, 15, 2017.

14. Thode HJ. (2002), Testing folr normality, New York, Marcel Dekker.

15. Viessman, W., Lewis, G. L. (2003), Introduction to Hydrology (5th ed.), Prentice Hall. 